\title{
Selvmordsstatistikkens pålitelighet i Skandinavia - en retrospektiv gjennomgang av 1800 dødsfall
}

\author{
Av Ingvild Tøllefsen
}

\section{SAMMENDRAG}

En pålitelig dødsårsaksstatistikk er viktig for planlegging og kvalitetssikring av helsetjenesten. Studier har vist at det særlig kan være utfordrende å klassifisere selvmord og noen ulykker. Hensikten med denne studien var å studere påliteligheten av selvmordsstatistikken i Skandinavia. Informasjon om totalt 1800 dødsfall registrert i 2008 ble hentet ut fra dødsårsaksregisteret i de tre skandinaviske landene. Det ble hentet ut 600 dødsfall fra hvert land, der 200 var klassifisert som selvmord, 200 som ulykker eller ubestemt dødsmåte og 200 naturlige dødsfall. Åtte fagpersoner (psykiatere, rettsmedisiner, personer med kodekompetanse fra dødsårsaksregisteret) fra de tre landene re-klassifiserte disse dødsfallene. Totalt var enigheten mellom fagpersonene og dødsårsaksregisteret hhv. 88 \%, $81 \%$ og $90 \%$ i det norske, svenske og danske materialet. Omtrent $3 \%$ av dødsfall som var klassifisert som ulykke eller naturlig død ble re-klassifisert som selvmord. To av fagpersonene gjorde en ny re-klassifisering av det norske og svenske materialet, der mer informasjon var tilgjengelig. De to fagpersonene re-klassifiserte da flere dødsfall som selvmord, hhv. $9 \%$ i det norske materialet og $21 \%$ av dem som var registrert med ubestemt dødsmåte i det svenske materialet. En stor andel av registrerte selvmord ble også klassifisert som selvmord av fagpersonene. Få ulykker og naturlig dødsfall ble re-klassifisert som selvmord.

Valid mortality statistics are important for health-care planning and research. Suicides and accidents often present a challenge in the classification of the manner of death. The aim of this study was to analyze the reliability of the national suicide statistics in Scandinavia. The cause of death registers in Norway, Sweden and Denmark retrieved available information on a sample of 1800 deaths in 2008, 600 from each country. Two hundred were classified in the registers as suicides, 200 as accidents or undetermined and 200 as natural deaths. Eight people with different medical expertise (psychiatry, forensic pathology and public health) re-evaluated these deaths. In total, $81 \%, 88 \%$ and $90 \%$ of deaths registered as suicide in the official mortality statistics were confirmed by experts using the Swedish, Norwegian and Danish datasets, respectively. About $3 \%$ of deaths classified as accidents or natural deaths in the cause of death registers were reclassified as suicides. Two of the experts did a second reclassification based on additional information, then $9 \%$ of the natural deaths and accidents were reclassified as suicides in the Norwegian dataset, and $21 \%$ of the undetermined deaths were reclassified as suicides in the Swedish dataset. A high percentage of reported suicides were confirmed as being suicides. Few accidents and natural deaths were reclassified as suicides.

SELVMORD ER ET stort folkehelseproblem. I følge tall fra verdens helseorganisasion (WHO), tar over 800.000 personer hvert år sitt eget liv. I 2015 ble det registrert henholdsvis 1179, 590 og 564 dødsfall ved selvmord i Sverige, Norge og Danmark (Socialstyrelsen, 2015; Statens Serum Institut, 2015; The Norwegian Institute of Public Health, 2015). Dette tilsvarer omtrent 11-12 selvmord per 100.000 innbyggere per år for alle tre landene. Selvmordsratene har vært ganske like i Skandinavia de siste 15-20 årene, men utviklingen fra 1970 til 200o-tallet har vært ulik i de tre landene. I Norge økte selvmordsratene fra 1970 til 1988, med høyeste rate 16,7 per 100.000 innbyggere. Deretter falt ratene raskt frem til 1995, og de har deretter stabilisert seg på en rate rundt 11-12. I Danmark er ratene nå rundt en tredjedel av det de var i 1980, og i Sverige er de blitt halvert siden 1980 .

Alle dødsfall i Skandinavia blir registrert i Dødsårsaksregisteret i hvert av landene, og kodet i henhold til Verdens 


\section{Materiale}

Materialet til denne studien er innhentet fra dødsårsaksregisteret i Norge, Sverige og Danmark, og inneholder 1800 dødsfall, der personene var 18 år eller eldre, og døde i 2008. Det ble innhentet 600 dødsfall fra hvert land, og av disse dødsfallene var 200 registrert som selvmord, 200 som ulykke eller ubestemt dødsmåte og 200 som naturlig død i dødsårsaksregisteret. Se tabell 1 . Vi inkluderte alle selvmordsmetoder (ICD10: X6o-84, Y870), og hadde et utvalg av ulykker og naturlige dødsfall. Ulykker inkluderte trafikk- (ICD-10: Vo1-V99), forgiftning- (ICD-10: X40-X49), drukning(ICD-10: W65-W74) og brannulykker (ICD-10: XooXog). Det norske og svenske materialet inkluderte ikke alle trafikkulykker, men et utvalg av førerulykker som man antok kunne inneholde noen selvmord (ICD-10: V43-V45.5, V47-V48.5, V49.4). Det danske materialet inneholdt alle typer trafikkulykker. I tillegg inkluderte vi ubestemt dødsmåte (ICD-10: Y10-Y34, Y872) i det svenske materialet. Det ble ikke inkludert noen med ubestemt dødsmåte i det norske materialet siden det ikke var noen dødsfall som ble registrert som dette i 2008. Innenfor kategorien naturlig dødsfall inkluderte vi et utvalg av dødsårsaker der den underliggende dødsårsaken var en psykisk lidelse. Dette ble gjort for å få et utvalg med rapportert høyere selvmordsrisiko innenfor naturlige dødsfall. Disse

inkluderte rusmisbruk (ICD-10: F10-F19), psykoser (ICD-10: F20-F29), affektive lidelser (ICD-10: F30-F39) og personlighetsforstyrrelser (ICD-10: FF6o-69). Det danske materialet inneholdt også ukjent dødsårsak (ICD-10: R96-999). Alle dødsfallene ble trukket ut tilfeldig fra Dødsårsaksregisteret i hvert land og ut i fra bestemte diagnosegrupper som er nevnt ovenfor. Det norske og svenske materialet var stratifisert ved dødsårsaksregisteret. I det danske materialet brukte vi de offisielle tallene for å beregne antall dødsfall i hver kategori, slik at disse skulle bli sammenliknbare med det norske og svenske materialet.

Re-klassifikasjon av dødsfallene var basert på informasion på dødsattesten og obduksjonsrapporter. I det norske materialet var det blitt utført 325 (54\%) obduksjoner, og 86 av disse inneholdt en fullstendig obduksjonsrapport. De øvrige 239 dødsfallene inneholdt en revidert dødsattest og resultatene fra obduksjonen, beskrevet ved SNOMED-koder (terminologi som benyttes av patologer). Det svenske materialet inneholdt ingen fullstendig obduksjonsrapport, selv om 483 (81\%) av dødsfallene var blitt obdusert. Disse inneholdt en revidert dødsattest. Den danske dødsattesten (elektronisk siden 2007) er mer utfyllende enn den norske og svenske, og har rubrikker der man kan fylle inn klinisk informasjon, informasjon fra dødsstedet og eventuelt en sammenfatning av liksyn eller obduksjon. I det danske materialet var en obduksjon blitt utført hos 191 (32\%) av dødsfallene, og informasjon om denne var inkludert i dødsattesten.
TABELL 1. Datamateriale inndelt i dødsmåter og dødsårsaker

\begin{tabular}{|c|c|c|c|}
\hline $\begin{array}{l}\text { Dødsmåte og dødsårsak } \\
\text { (ICD-10 koder) }\end{array}$ & $\begin{array}{r}\text { Norge } \\
(n)\end{array}$ & $\begin{array}{r}\text { Sverige } \\
\text { (n) }\end{array}$ & $\begin{array}{r}\text { Danmark } \\
\text { (n) }\end{array}$ \\
\hline Selvmord (X60-84, Y87.0) & 200 & 200 & 200 \\
\hline Ulykker & 200 & 200 & 199 \\
\hline Trafikkulykker (V01-99) & 29 & 34 & 45 \\
\hline Forgiftningsulykker (X40-49) & 129 & 70 & 104 \\
\hline $\begin{array}{l}\text { Brann- og drukningsulykker } \\
\text { (W65-74, X00-09) }\end{array}$ & 42 & 36 & $51^{*}$ \\
\hline $\begin{array}{l}\text { «Ubestemt dødsmåte» } \\
\text { (Y10-34, Y87.2) }\end{array}$ & 0 & 60 & 0 \\
\hline Naturlige dødsfall & 200 & 200 & 200 \\
\hline Rusmisbruk (F10-19) & 155 & 149 & 59 \\
\hline $\begin{array}{l}\text { Psykoser, affektive lidelser } \\
\text { og personlighetsforstyrrelser } \\
\text { (F20-39, F60-69) }\end{array}$ & 45 & 51 & 81 \\
\hline $\begin{array}{l}\text { «Ukjent dødsårsak» } \\
\text { (R96-999) }\end{array}$ & 0 & 0 & 59 \\
\hline TOTAL & 600 & 600 & 599 \\
\hline
\end{tabular}

Det norske og svenske materialet inkluderte et utvalg av trafikkulykker, mens det danske materialet inkluderte alle trafikkulykker (ICD-10: V01-V99). *En person ble ekskludert grunnet alder $<18$ år.

\section{Metode}

Alle dødsfallene ble av-identifisert og gitt et tilfeldig ID-nummer før fagpersonene vurderte dødsfallene individuelt. Kjønn og alder for hvert dødsfall var kjent for fagpersonene. Det var åtte fagpersoner som vurderte dødsfallene, tre psykiatere og tre rettsmedisinere fra hvert av de tre skandinaviske landene og to fagpersoner fra Norge og Danmark med kodekompetanse innen dødsårsaksregistrering. En fagperson fra Sverige med kodekompetanse innen dødsårsaksregistrering måtte trekke seg under studien. Etter protokoll inndelte vi de 600 dødsfallene fra hvert land inn i 12 grupper med 50 dødsfall i hver gruppe. Dette ble giort for å forsikre oss om at dødsfall fra alle tre landene ble vurdert av fagpersoner innen hver spesialitet, og at hvert dødsfall ble vurdert av minst tre fagpersoner. I denne studien vurderte den norske psykiateren 1000 dødsfall (6oo norske, 200 svenske og 200 danske dødsfall). Den norske og svenske rettsmedisineren og den norske fagpersonene med kodekompetanse vurderte 800 dødsfall (400 fra eget land og 200 fra hvert av de to andre landene). Den svenske psykiateren og de tre danske fagpersonene vurderte 600 dødsfall hver (200 dødsfall fra hvert land). Fagpersonene benyttet et skjema for hvert dødsfall og krysset av for dødsmåte, dødsårsak og deretter grad av sikkerhet i re-klassifiseringen (1: 
TABELL 2. Demografiske data

\begin{tabular}{|c|c|c|c|c|}
\hline & Totalt & Norge & Sverige & Danmark \\
\hline Totalt antall (n) & 1799 & 600 & 600 & $599^{*}$ \\
\hline Menn, n (\%) & $1223(68 \%)$ & 432 (72 \%) & $403(67 \%)$ & $388(65 \%)$ \\
\hline Alder, gj.snitt (SD) & $56(20)$ & $54(19)$ & $56(19)$ & $58(21)$ \\
\hline Obduksjonsrapporter & 998 (56 \%) & 325 (54 \%) & $483(81 \%)$ & $190(32 \%)$ \\
\hline Naturlige dødsfall & & $32(16 \%)$ & $108(54 \%)$ & $15(8 \%)$ \\
\hline Selvmord & & $136(68 \%)$ & 192 (96 \%) & $36(18 \%)$ \\
\hline Ulykker & & 157 (79 \%) & $124(89 \%)$ & $139(70 \%)$ \\
\hline Ubestemt dødsmåte & & & 59 (98 \%) & \\
\hline
\end{tabular}

*En person ble ekskludert grunnet alder $<18$ år.

sikker, 2: ganske sikker, 3: usikker, 4: for lite informasjon for å bestemme dødsmåte og dødsårsak, 5: for lite informasjon for å bestemme dødsårsak. I denne artikkelen er 1 og 2 slått sammen til «sikker» og 4 og 5 slått sammen til «for lite informasjon», mens gruppe tre er uendret («usikker»).

Ny re-evaluering av det norske og svenske materialet Grunnet lite informasjon om flere dødsfall i det norske og svenske materialet ble det innhentet mer informasjon for dødsfall der dette var tilgiengelig. Obduksjonsrapport og politirapport ble derfor innhentet, og aktuelle dødsfall ble re-klassifisert på nytt av den norske psykiateren og rettsmedisineren. Vi innhentet rettsmedisinsk rapport for 180 norske dødsfall, alle disse fra Folkehelseinstituttet (vi inkluderte ikke 59 dødsfall som var obdusert ved ulike institusioner eller sykehus andre steder i Norge). Fra Sverige innhentet vi rettsmedisinsk rapport og eventuelt politirapport for 483 dødsfall. Den norske psykiateren re-klassifiserte 180 norske dødsfall, og den norske rettsmedisineren re-klassifiserte 124 norske dødsfall i den andre re-evalueringen. I den andre re-evalueringen av det svenske materialet, re-klassifiserte de to fagpersonene de samme 200 dødsfallene som de vurderte i første runde, samt alle dødsfall som var klassifisert som ubestemt dødsmåte i det svenske dødsårsaksregisteret. Den norske psykiateren re-klassifiserte 235 svenske dødsfall, og den norske rettsmedisineren re-klassifiserte 247 svenske dødsfall i den andre re-evalueringen.

\section{Statistikk}

Data ble analysert med SPSS V.21.o (Armonk, New York). Ved analyse av demografiske forskjeller brukte vi chi-kvadrat test $\left(\chi^{2}\right)$, og for å sammenlikne dødsmåter mellom dødsårsaksregisteret og fagpersonene brukte vi krysstabeller. Enighet om selvmord (i prosent) ble beregnet ved å summere det totale antallet vurderte selvmord dividert med totalt antall selvmord som var blitt registrert i dødsårsaksregisteret. P-verdi < 0.05 ble ansett som signifikant.

\section{Etikk}

Denne studien er godkjent av REK Sørøst. Vi har innhentet godkjennelse fra Personvernombudet ved Oslo Universitetssykehus, Folkehelseinstituttet og Riksadvokaten i Norge. I tillegg har vi innhentet godkjennelse fra Socialstyrelsen og Rättsmedicainalverket i Sverige og Sundhedsstyrelsen i Danmark.

\section{Resultater}

\section{Demografi}

Totalt i hele materialet var det signifikant flere menn (68 \% menn, $\mathrm{p}<0.001$ ). Obduksjonsfrekvensen var høyest i Sverige ( $81 \%$ ) og lavest i Danmark (32\%). I Norge var obduksjonsfrekvensen $54 \%$. Se tabell 2. Den hyppigste selvmordsmetoden var henging og kvelning: $35 \%$ i det norske og svenske materiale og $38 \%$ i det danske materialet $(\mathrm{p}=0.77)$. Se tabell 3. Selvmord ved

TABELL 3. Fordeling av selvmordsmetoder i uthentet materiale

\begin{tabular}{|l|r|r|r|}
\hline Selvmordsmetoder & $\begin{array}{l}\text { Norge } \\
n(\%)\end{array}$ & $\begin{array}{l}\text { Sverige } \\
n(\%)\end{array}$ & $\begin{array}{l}\text { Danmark } \\
n(\%)\end{array}$ \\
\hline Selvmord ved forgiftning & 47 & 58 & 61 \\
\hline $\begin{array}{l}\text { Selvmord med henging } \\
\text { og kvelning }\end{array}$ & $\begin{array}{r}(24 \%) \\
(35 \%)\end{array}$ & $\begin{array}{r}(35 \%) \\
(31 \%)\end{array}$ \\
\hline $\begin{array}{l}\text { Selvmord ved skytevåpen } \\
\text { eller eksplosiver }\end{array}$ & 36 & 20 & 76 \\
\hline $\begin{array}{l}\text { Selvmord ved drukning, } \\
\text { brann, hopp eller ved } \\
\text { kollisjon med kjøretøy }\end{array}$ & $(18 \%)$ & $(10 \%)$ & $(9 \%)$ \\
\hline
\end{tabular}


FIGUR 1. Re-klassifisering av selvmord i det norske materialet NORSK MATERIALE

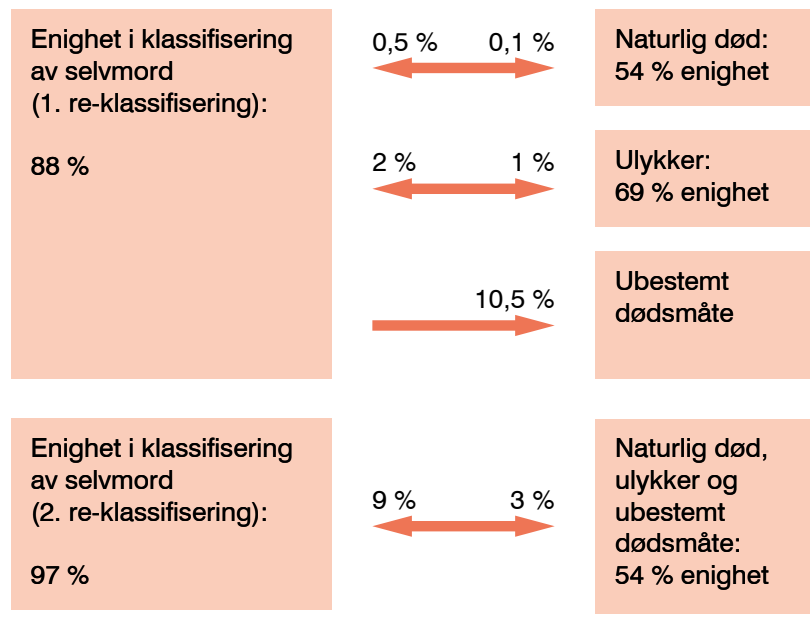

FIGUR 2. Re-klassifisering av selvmord i det svenske materialet

\section{SVENSK MATERIALE}
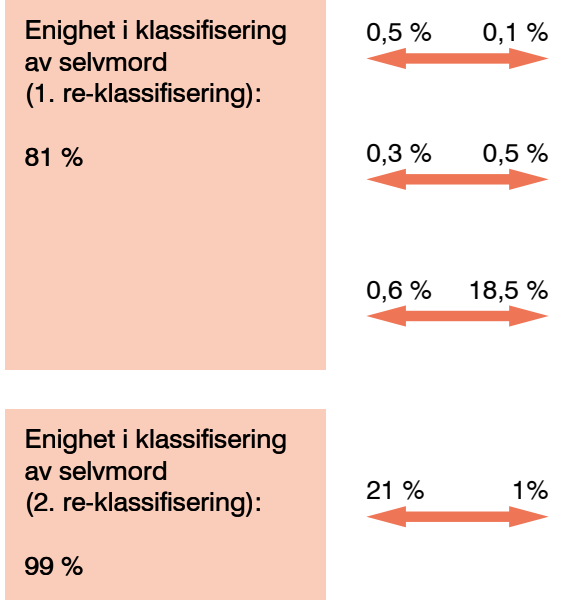

Naturlig død: $73 \%$ enighet

Ulykker: $69 \%$ enighet

Ubestemt dødsmåte: $94 \%$ enighet

Naturlig død, ulykker og ubestemt dødsmåte: $54 \%$ enighet

FIGUR 3. Re-klassifisering av selvmord i det danske materialet

\section{DANSK MATERIALE}

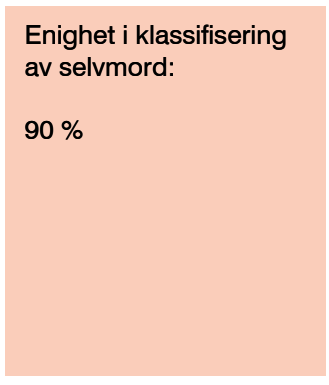

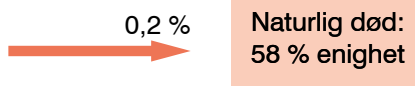

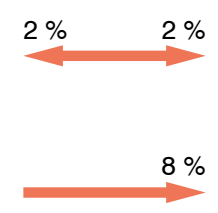

Ulykker: $78 \%$ enighet

Ubestemt dødsmåte forgiftning var nest hyppigste metode: $24 \%$ i det norske materialet, $29 \%$ i det svenske materialet og $31 \%$ i det danske materialet $(\mathrm{p}=0.26)$. Selvmord ved skytevåpen eller eksplosiver var signifikant høyere i det norske materialet $(\mathrm{p}=0.01)$.

\section{Re-klassifikasjon}

I det norske materialet var det totalt $88 \%$ (range 54-100 \%) enighet mellom fagpersonene og dødsårsaksregisteret. Totalt ble 11 \% (range o-44 \%) av selvmordene re-klassifisert av fagpersonene til ubestemt dødsmåte, mens $1 \%$ ble re-klassifisert til ulykke og $0.1 \%$ til naturlig dødsfall. Totalt ble $2 \%$ av ulykkene og $0,5 \%$ av naturlige dødsfall re-klassifisert til selvmord av fagpersonene.

I det svenske materialet var det totalt $81 \%$ (range 39-100 \%) enighet mellom fagpersonene og dødsårsaksregisteret. Totalt ble $18 \%$ (range o-59\%) av selvmordene re-klassifisert av fagpersonene til ubestemt dødsmåte, mens $0,5 \%$ ble re-klassifisert til ulykke og $0,1 \%$ til naturlig dødsfall. Totalt ble 0,3\% av ulykkene, 0,5\% av naturlige dødsfall og o,6 \% av ubestemt dødsmåte re-klassifisert til selvmord av fagpersonene.

I det danske materialet var det totalt $90 \%$ (range 78-98 \%) enighet mellom fagpersonene og dødsårsaksregisteret. Totalt ble $8 \%$ (range o-20\%) av selvmordene re-klassifisert av fagpersonene til ubestemt dødsmåte, mens $2 \%$ ble re-klassifisert til ulykke og o,2 \% til naturlig dødsfall. Totalt ble 2,5\% av ulykkene og ingen naturlige dødsfall re-klassifisert til selvmord av fagpersonene.

Andre re-klassifisering av det norske og svenske materialet Den norske psykiateren og rettsmedisineren giorde en ny re-klassifisering av det norske og svenske materialet, der mer informasjon var tilgiengelig. I det norske materialet var det totalt $97 \%$ enighet mellom de to fagpersonene og dødsårsaksregisteret. Totalt ble $3 \%$ av selvmordene re-klassifisert av fagpersonene til ulykke, naturlig død eller ubestemt dødsmåte. Totalt ble $9 \%$ av ulykkene og naturlige dødsfall re-klassifisert til selvmord av de to fagpersonene.

I det svenske materialet var det totalt $99 \%$ enighet mellom de to fagpersonene og dødsårsaksregisteret. Totalt ble $1 \%$ av selvmordene re-klassifisert av fagpersonene til ulykke, naturlig død eller ubestemt dødsmåte. Totalt ble $21 \%$ av dødsfallene med ubestemt dødsmåte re-klassifisert til selvmord av de to fagpersonene.

\section{Grad av sikkerhet i re-klassifiseringen}

For alle dødsfall i det norske materialet var fagpersonene sikre på dødsmåte i 69 \% av dødsfallene, usikre i 8 \% og mente de hadde for lite informasion for å vurdere dødsmåte i 23 \% av dødsfallene. Det var blant naturlige dødsfall (43\%) og drukningsulykker (45\%) det ble rapportert oftest om for lite informasjon for å bestemme dødsmåte. Av alle selvmord ble det rapportert mest usikkerhet og manglende informasion ved selvmord ved forgiftning. Se tabell 4 . 
TABELL 4. Grad av sikkerhet i re-klassifisering av selvmord

\begin{tabular}{|l|r|r|r|r|r|r|}
\hline & \multicolumn{2}{|c|}{ Norge } & \multicolumn{2}{c|}{ Sverige } & \multicolumn{2}{c|}{ Danmark } \\
\hline Gelvmord & Sed forgiftning & $\begin{array}{c}\text { Andre } \\
\text { selvmord }\end{array}$ & $\begin{array}{c}\text { Selvmord } \\
\text { ved forgiftning }\end{array}$ & $\begin{array}{c}\text { Andre } \\
\text { selvmord }\end{array}$ & $\begin{array}{c}\text { Selvmord } \\
\text { ved forgiftning }\end{array}$ & $\begin{array}{c}\text { Andre } \\
\text { selvmord }\end{array}$ \\
\hline Sikker & $145(73 \%)$ & $571(92 \%)$ & $105(59 \%)$ & $352(85 \%)$ & $131(81 \%)$ & $346(96 \%)$ \\
Usikker & $17(9 \%)$ & $19(3 \%)$ & $29(16 \%)$ & $20(5 \%)$ & $9(6 \%)$ & $4(1 \%)$ \\
For lite informasjon & $36(18 \%)$ & $33(5 \%)$ & $45(25 \%)$ & $43(10 \%)$ & $21(13 \%)$ & $9(3 \%)$
\end{tabular}

Fagpersonenes vurdering av grad av sikkerhet i re-klassifisering av selvmord ved forgiftning og selvmord med andre metoder.

For alle dødsfall i det svenske materialet var fagpersonene sikre på dødsmåte i $68 \%$ av dødsfallene, usikre i 9 \% og mente de hadde for lite informasion for å vurdere dødsmåte i $23 \%$ av dødsfallene. Det var blant dødsfall med ubestemt dødsmåte (53\%) det ble rapportert oftest om for lite informasjon for å bestemme dødsmåte.

For alle dødsfall i det danske materialet var fagpersonene sikre på dødsmåte i 69 \% av dødsfallene, usikre i 9 \% og mente de hadde for lite informasion for å vurdere dødsmåte i $22 \%$ av dødsfallene. Det var blant naturlige dødsfall (46\%) og drukningsulykker (22\%) det ble rapportert oftest om for lite informasjon for å bestemme dødsmåte.

\section{Diskusjon}

Denne studien der åtte fagpersoner re-klassifiserte 1800 dødsfall fra Norge, Sverige og Danmark viser at nesten alle klassifiserte selvmord er selvmord. Totalt var enigheten mellom fagpersonene og Dødsårsaksregisteret hhv. $88 \%, 81 \%$ og $90 \%$ i det norske, svenske og danske materialet. Omtrent $3 \%$ av dødsfall som var klassifisert som ulykke eller naturlig død ble re-klassifisert som selvmord. To av fagpersonene giorde en ny re-klassifisering av det norske og svenske materialet, der mer informasion var tilgiengelig. De to fagpersonene re-klassifiserte da flere dødsfall som selvmord, hhv. $9 \%$ i det norske materialet og $21 \%$ av de som var registrert med ubestemt dødsmåte i det svenske materialet. Særlig blant ubestemt dødsmåte, drukningog forgiftningsulykker ble det rapportert manglende informasjon for å bestemme dødsmåte.

Informasjon om hvert dødsfall som ble evaluert $\mathrm{i}$ denne studien baserte seg på tilgiengelig informasjon fra Dødsårsaksregisteret. Det var en stor forskiell på hvor mye informasion fagpersonene hadde tilgiengelig for hvert dødsfall fra de tre landene, der den danske dødsattesten var mer utfyllende enn den norske og svenske. Det er sannsynlig at legen som fylte ut dødsattesten for noen av dødsfallene hadde mer informasjon om dødsfallet enn det som var beskrevet på dødsattesten. I denne studien var det størst enighet i det danske materialet, og minst i det svenske. En viktig forskjell mellom de tre landene når det gielder organisering og registrering av dødsfall, er at det i Danmark utføres liksyn av politi og en embetslæge av alle unaturlige dødsfall (Tollefsen et al., 2016). Med liksyn menes en undersøkelse av den avdøde og interviu av pårørende/vitner etc. I Norge og Sverige utføres liksyn i svært liten grad, og for alle tre land er det politiet som bestemmer om det skal utføres en rettsmedisinsk obduksjon. I dette materialet var det utført flest rettsmedisinske undersøkelser i det svenske materialet, og minst i det danske. En rettsmedisinsk undersøkelse er nyttig for å bestemme dødsårsak (eks. forgiftning), mens et liksyn i større grad kan bestemme dødsmåte. I første re-klassifikasjon var det mer informasjon om dødsfallene i det danske materialet, og dette kan delvis forklare at fagpersonene var mest enige i re-klassifiseringen av det danske materialet.

Andre studier som har studert påliteligheten av selvmordsstatistikken har benyttet seg hovedsakelig av tre metoder. Den ene metoden består i samme metode som vi har benyttet i denne studien, der man re-klassifiserer dødsfall fra ulike dødsmåter (eks. ulykke, naturlig dødsfall) eller dødsårsaker (eks. forgiftning, drukning). Den andre metoden baserer seg på statistiske analyser, der man beregner andel under- eller overrapportering ved å sammenlikne ratene for ulike relevante dødsårsaker, f.eks. selvmord og ubestemt dødsmåte (Kapusta et al., 2011; Kolmos \& Bach, 1987; Rockett et al., 2010). I de senere årene har man lagt til alle dødsfall registrert som ubestemt dødsmåte til selvmordsratene i Storbritannia. I Storbritannia er prosedyrene ved dødsårsaksregistrering annerledes enn i Skandinavia, der dødsfall blir registrert som selvmord kun i de tilfeller der det ikke er noe tvil om dødsfallet er et selvmord. I denne studien ble kun $21 \%$ av dødsfall med ubestemt dødsmåte i Sverige re-klassifisert som selvmord, så det vil trolig ikke bli riktig å legge alle svenske dødsfall med ubestemt dødsmåte til selvmordsratene. I Sverige blir omtrent 300-400 døds- 
fall registrert som ubestemt dødsmåte hvert år. Hvis man tenker seg at $20 \%$ av alle dødsfall med ubestemt dødsmåte er uregistrerte selvmord, ville selvmordsratene for 2008 okt fra 12.7 til 13.4 selvmord per 100.000 innbyggere. En tredje metode å vurdere påliteligheten av selvmordsstatistikken baserer seg på å sammenlikne rater fra to ulike registre, f.eks. Dødsårsaksregisteret og f.eks. et register over veitrafikkulykker (Elnour \& Harrison, 2009; Hlady \& Middaugh, 1988; Lindeman, Hirvonen, Hakko, \& Lonnqvist, 1995). Hvilken metode som benyttes for å studere påliteligheten av selvmordsstatstikken vil variere fra land til land, avhengig av registreringspraksis og hvilke registre som finnes. Funnene i denne studien konkluderer, i likhet med studiene fra Skandinavia på 1980-tallet (Ekeberg et al., 1985; Kolmos \& Bach, 1987), at likhetene i selvmordsrate i de Skandinaviske landene er reelle. Det er få andre studier som har re-klassifisert og utvekslet dødsfall mellom to eller flere land. I en studie fra 1975, der 40 dødsfall ble utvekslet mellom Danmark og England, fant man at de danske fagpersonene konsekvent klassifiserte flere selvmord enn de engelske fagpersonene (Atkinson, Kessel, \& Dalgaard, 1975).

\section{Styrker og svakheter med studien}

En styrke ved denne studien er at materialet innhentet fra Dødsårsaksregisteret er basert på et relativt stort antall dødsfall fra de tre skandinaviske landene. Dette giør at demografiske data er sammenliknbare med den offisielle statistikken, og vi kan sammenlikne data mellom land. Denne studien inkluderte flere ulike dødsmåter og dødsårsaker der det kan være noen uregistrerte selvmord. Dette utvalget var basert på funn fra tidligere studier, der man har funnet at det sannsynligvis er flest selvmord blant ulike ulykkekategorier

og ubestemt dødsmåte. I tillegg hadde vi med naturlige dødsfall med psykisk lidelse som underliggende dødsårsak. Dette ble giort for å få et utvalg dødsfall med rapportert høyere selvmordsrisiko, der man kan tenke seg at det er noen uregistrerte selvmord. En annen styrke er at dødsfallene ble vurdert av ulike fagpersoner fra de tre landene. Styrken i dette er at fagpersonene

\section{En hoy andel} registrerte selvmord ble vurdert til å være selvmord av fagpersonene. vurderer dødsfallene fra et noe ulikt perspektiv. Fagpersonene som har kodekompetanse fra Dødsårsaksregisteret har god kompetanse i WHOs koderegelverk (ICD-10). Rettsmedisinere har spesialkompetanse i å vurdere dødsmåte og

dødsårsak, mens psykiatere har spesialkompetanse i å vurdere motiv og atferd. At det er stor forskjell mellom de tre landene når det gielder tilgiengelig informasion om hvert dødsfall er en metodisk svakhet. Den store forskjellen i vurderingen mellom fagpersonene kan trolig i stor grad forklares ved at det var lite informasjon for en del dødsfall, særlig i det norske og svenske materialet, og at noen fagpersoner klassifiserte en del selvmord som ubestemt dødsmåte. En annen svakhet med studien er at det var kun to fagpersoner fra Norge som giorde en ny re-klassifisering der de hadde mer informasjon tilgiengelig.

\section{Konklusjon}

En høy andel registrerte selvmord ble vurdert til å være selvmord av fagpersonene. I de tilfellene der det var diskrepans mellom selvmord registrert i 
Dødsårsaksregisteret og vurderingen til fagpersonene, ble selvmord vurdert som ubestemt dødsmåte av fagpersonene. Det var få ulykker og naturlige dødsfall som ble re-klassifisert som selvmord av fagpersonene, slik at den totale selvmordsandelen ble ikke økt. Grunnet manglende informasjon hos noen av dødsfallene, kan man ikke utelukke en viss grad av under-rapportering av selvmord.

Levert: 22.02.17 - Revidert: 10.05.17 - Godkjent: 16.05.17

\section{REFERANSELISTE}

Atkinson, M. W. et al. (1975). The comparability of suicide rates. Br.I.Psychiatry, 127, 247-256.

Breiding, M. I. \& Wiersema, B. (2006). Variability of undetermined manner of death classification in the US. Inj.Prev., 12 Suppl 2, ii49-ii54.

Caribe, A. C. et al. (2012). Religiosity as a protective factor in suicidal behavior: a case-control study. Journal of Nervous and Mental Disease, 200, 863-867.

Ekeberg, O. et al. (1985). The reliability of suicide statistics in Norway. Tidsskr Nor Laegeforen., 105, 123-127.

Elnour, A. A. \& Harrison, I. (2009). Suicide decline in Australia: where did the cases go? Aust.N.Z.I.Public Health, 33, 67-69.

Hlady, W. G. \& Middaugh, I. P. (1988). The underrecording of suicides in state and national records, Alaska, 1983-1984. Suicide Life Threat.Behav., $18,237-244$.

Kapusta, N. D. et al. (2011). Declining autopsy rates and suicide misclassification: a cross-national analysis of 35 countries. Arch.Gen.Psychiatry, 68, 1050-1057.

Kolmos, L. \& Bach, E. (1987). Sources of error in registering suicide. Acta Psychiatr.Scand.Suppl, 336, 22-43.

Lindeman, S. M. et al. (1995). Use of the National Register of medico-legal autopsies in epidemiological suicide research. Int.J.Legal Med., 107, 306-309.
Lorant, V. et al. (2005). Socio-economic inequalities in suicide: a European comparative study. Br.I.Psychiatry, 187, 49-54.

Mackenbach, I. P. et al. (1987). Certification and coding of two underlying causes of death in The Netherlands and other countries of the European Community. J.Epidemiol.Community Health, 41, 156-16o.

Page, A. et al. (2014). Suicide in young adults: psychiatric and socioeconomic factors from a case-control study. BMC.Psychiatry, 14, 68.

Rockett, I. R. et al. (2010). Race/ethnicity and potential suicide misclassification: window on a minority suicide paradox? BMC.Psychiatry, 10, 35

The National Board of Health and Welfare in Sweden. Statistikdatabas. Retriewed from www.socialstyrelsen.se.

Sundhedsdatastyrelsen. Tabel over dodsårsager. Retriewed from: www.esundhed.dk

The Norwegian Institute of Public Health. Dødsårsaksregisteret. Retrieved from www.statistikkbank.fhi.no/dar/.

Tidemalm, D., Runeson, B., Waern, M., Frisell, T., Carlstrom, E., Lichtenstein, P. et al. (2011). Familial clustering of suicide risk: a total population study of 11.4 million individuals. Psychol.Med., 41, 2527-2534.

Tollefsen, I. M. et al. (2015). Are suicide deaths under-reported? Nationwide re-evaluations of 1800 deaths in Scandinavia. BMI Open., 5 (11), eoog120.

Tollefsen, I. M. et al. (2012). The reliability of suicide statistics: a systematic review. BMC.Psychiatry, 12, 9 .

Tollefsen, I. M. et al. (2016). Differing Procedures for Recording Mortality Statistics in Scandinavia. Crisis, 1-8.

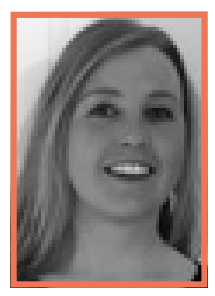

INGVILD TØLLEFSEN er PhD og lege i spesialisering ved akuttmedisinsk avdeling, Oslo Universitetssykehus Ullevål. 